\title{
ENTRE GALOS E MATADOUROS: VIOLÊNCIA, VIDA SOCIAL E FAMIILIA EM UMA COMUNIDADE CAMPONESA DO SUMAPAZ
}

Santiago Alvarez

Here by it is manifest, that during the time men live without a common power to keep them all in awe, they are in that condition which is called warre; and such a warre, is of every man against every man (Hobbes 1975 [1651]:64).

\section{Introdução}

Quando dei início ao meu trabalho de campo nos Andes colombianos, pretendia estudar formas de violência organizada: os narcotraficantes, a guerrilha, o próprio Estado colombiano. A ocorrência, no passado, de uma rebelião camponesa bem-sucedida, que expulsou os antigos proprietários de terra da região, falava-nos, supostamente, de solidariedade camponesa. Nada pressagiava meu encontro com as vinganças de sangue entre famílias de camponeses que se matavam umas às outras, até o extermínio.

Neste artigo, tento refletir, por meio da observação de um grupo familiar específico e da descrição de suas principais atividades, sobre a relevância particular da violência ${ }^{1}$ entre pessoas de um mesmo estrato social camponês em uma comunidade rural do altiplano cundiboyacense. Nesta comunidade, a que vou me referir aqui como Nómeque, situada ao pé do Páramo de Sumapaz*, desenvolvi durante catorze meses uma pesquisa antropológica baseada principalmente no método da observação participante.

\footnotetext{
* o Sumapaz é uma região situada nos Andes orientais, ao sul da capital Bogotá, no departamento da Cundimarca; cundiboyacense refere-se provavelmente à região fronteiriça entre os departamentos de Cundimarca e Boyacá [N.T.].
} 
Tendo em conta os antecedentes da luta camponesa na região, descritos, entre outros, por M arulanda (1991:74) e Londoño (1993:58-59), umas das alternativas que se me apresentavam era focalizar a análise nos conflitos do campesinato com outras classes sociais e com o Estado nacional. Estes, se nos atemos aos estudos históricos mencionados, parecem ter estado no centro da problemática regional no período da colonização camponesa e durante as lutas agrárias que tiveram como conseqüência o desmantelamento das grandes fazendas e a divisão da terra. Tal foco estaria em concordância com a maioria das análises do campesinato na região andina, baseadas preferencialmente na investigação das "estratégias camponesas de sobrevivência" (ver Stern 1990:15) e sua relação com os movimentos políticos locais e nacionais.

Embora eu considerasse que o momento da "rebelião camponesa" objeto clássico dos estudos sobre o campesinato nos anos 60 - se havia encerrado ou se encontrava em estado latente, pensava ainda que o centro de minha investigação pudesse consistir no estudo da "resistência camponesa", das "armas dos fracos" (tomando-se de empréstimo o feliz título de J ames Scott) e de sua relação com um movimento guerrilheiro de caráter "defensivo" que, inserido na comunidade camponesa, a protegia das ameaças de outros atores sociais.

Para Scott (1985:29), assim como para outros (Adas 1979; Hobsbawm 1983; Isaacman 1980), certas formas cotidianas de resistência - diminuição do ritmo de trabal ho, sabotagem, roubo etc. - eram expressões de uma luta de classe camponesa cujo objetivo não era a rebelião ou a revolução, mas que, no entanto, atacavam e alfinetavam as relações de poder existentes.

Contra minhas expectativas, porém, e levando em consideração o fato de que Nómeque se encontrava em uma zona de conflito entre o Estado e a guerrilha, uma vez em campo não pude deixar de registrar a enorme relevância do fenômeno que Isaacman denomina "dissensão interna" (1980:15-56), pelo que me refiro aos conflitos existentes no interior da comunidade. O grau de tensão e o nível de agressão no seio desta se revelaram altamente significativos. Graves conflitos entre famílias são sistematicamente resolvidos por meio da vingança de sangue. Em Nómeque, são numerosos os exemplos de enfrentamentos entre famílias inimigas que resultaram no quase total aniquilamento de seus membros masculinos. Essas experiências se conservam traumaticamente na memória coletiva dos moradores ${ }^{2}$. A violência recíproca que afeta a comunidade em questão constituiu, portanto, o centro do trabal ho de campo realizado e é o principal objeto deste texto. 
A família extensa é o grupo mínimo em que se expressa a solidariedade social e que participa ativamente da vingança. No caso das famílias estudadas em Nómeque, essa solidariedade, quando se trata de vendetas, se limitava aos irmãos, meios-irmãos e, mais excepcionalmente, primos irmãos ${ }^{3}$. As redes sociais locais são bastante frouxas, e atribui-se pouca importância à instituição do compadrio como criadora de laços duráveis - com efeito, em al guns casos as famílias em conflito mantinham vínculos de compadrio entre si. Durante meu trabalho de campo, as famílias envolvidas em vinganças viviam sua vida na comunidade sem serem perseguidas ou questionadas por qualquer autoridade estatal, embora caiba esclarecer que, nesse período, a delegacia de polícia fora abandonada após um ataque guerrilheiro que a destruiu completamente, matando vários de seus defensores. Este fato reforçava a ineficácia do sistema legal.

J acob Black-Michaud, em Feuding societies, mostra que, para além das sutis distinções que se possam estabelecer entre a vingança propriamente dita e o feud - basicamente, ao contrário deste último, a vingança seria indiscriminada e não admitiria compensação -, ambos estão interconectados e suas diferenças desaparecem nas práticas dos atores (Black-Michaud 1975:19-20). Neste caso particular, prefiro falar em vingança de sangue ou vendeta. Encontrei em outros casos que estudei uma tentativa da guerrilha de mediar as partes, visando pôr termo, ao menos temporariamente, aos conflitos, o que os aproximaria da definição de feud (ver Black-M ichaud 1975:17) - embora seja necessário dizer que essas tentativas não foram particularmente efetivas, revelando-se incapazes de controlar as vendetas ou de regulamentá-las (ver Alvarez 1999).

A vendeta não é a única forma de violência verificada na comunidade, mas considero que seu estudo, empreendido de uma perspectiva distinta, pode fornecer elementos significativos para sugerir que, sob os conflitos que monopolizam as pesquisas e os discursos oficiais sobre a problemática da violência, subjaz na comunidade camponesa uma conflituosidade interna que merece ser objeto de investigação.

\section{Os Casares, açougue e matadouro}

M atasete lançou-se logo do cavalo, cortou-Ihe o esporão com uma facada e, gingando em torno dele e empunhando sua enorme adaga, enfiou-a na garganta até o punho, mostrando-a em seguida, fumegante e rubra, aos espectadores. Brotou da ferida uma torrente, exalou alguns bramidos roucos, vaci- 
lou e caiu o soberbo animal entre os gritos da chusma que proclamava Matasete vencedor e Ihe adjudicava como prêmio o matafome. Matasete estendeu, orgulhoso, pela segunda vez, o braço e a faca ensangüentada e se agachou para esfolá-lo com outros companheiros (Echeverría 1993 [1851]:85).

Os Casares são uma família composta, hoje, pela mãe viúva e cinco filhos homens. J untos, trabalham uma "fama" (açougue). Três dos irmãos Casares mantêm relações estáveis com mulheres com as quais coabitam, na maioria dos casos, desde que tiveram filhos em comum. Suas relações com as respectivas esposas, embora marcadas por maus-tratos e brigas, não diferem substancialmente das relações habituais entre os membros dos dois sexos características do grupo familiar na comunidade analisada (grupo no qual o homem que, ao menos semanalmente, volta bêbado para casa tarde da noite e bate na mulher constitui a norma e não a exceção).

O eixo da família na região é a mãe. É ela que se responsabiliza pela criação dos filhos, enquanto o pai, geralmente, se despreocupa da tarefa. Essa matrifocalidade se exprime em uma família como a dos Casares, composta por irmãos homens que cercam a mãe. O pai e um irmão mais novo morreram tragicamente há apenas um ano, como será oportunamente explicado. A situação econômica da família é bastante precária. Alugam o açougue, assim como também a casa onde moram. Existe uma acentuada diferença de idade entre o mais velho dos irmãos, de uns 40 anos, e o mais novo, que não chega aos 18. Nenhum deles cursou mais que os estudos primários.

Meu conhecimento da família Ramallo e minha relação com eles foram, por sua vez, muito menores. Isto se deveu principalmente a dois fatores: por um lado, minha relativa proximidade com os Casares fez pairar sobre mim a suspeita de alguma parcialidade e restringiu meu contato a apenas alguns parentes distantes dos Ramallo; por outro, os Ramallo deixaram de ir à vila depois dos primeiros episódios de vingança, e não tive mais oportunidade de vê-los, afora nos funerais de seus parentes. Tratava-se de uma família rural de melhor posição econômica, que possuía alguns hectares não muito distantes de Nómeque e que alugava aos Casares, antes do início do conflito, a casa onde estes moravam. A figura paterna representada pelo vel ho Ramallo era talvez a mais significativa, embora se dissesse que ele tinha dificuldades de controlar os filhos homens, famosos por sua ferocidade e violência. A família Ramallo era mais temida que amada. M eus informantes relacionavam-na com o roubo de gado e, de fato, alguns de seus membros haviam passado algum tempo na cadeia acusados desse delito. 
O açougue em que os Casares trabalham é um local pequeno, de uns sete metros de comprimento por uns quatro de largura, onde se vende carne quase todos os dias, à exceção das segundas-feiras e de alguns feriados. No açougue, a carne é exposta e dependurada em grandes ganchos. Na comunidade, constitui quase um lugar-comum a comparação de suas atividades como açougueiros com a sua participação em ações violentas. Uma vizinha manifestava seu terror ao ver "esses grandalhões manejando essas facas enormes, cortando carne". O sangue derramado no açougue é comparado ao sangue derramado nas vinganças.

O matadouro da comunidade é uma construção de planta baixa de uns vinte metros de comprimento por cinco de largura; do lado de fora, ficam os currais onde os bois esperam sua vez de serem sacrificados. Nele seria possível carnear ao mesmo tempo umas quatro reses, caso fosse necessário. Às quintas-feiras, os açougues preparam a carne para vender às sextas e, especialmente, aos sábados, dia do mercado. Os encarregados da lida são geralmente os empregados dos açougues ou os próprios açougueiros quando não possuem pessoal empregado. No caso particular dos Casares, eles mesmos se encarregam de lidar com o gado.

O matador, auxiliado por alguns companheiros, deve fazer o animal entrar no matadouro, amarrar sua cabeça e suas patas em argolas de ferro colocadas no chão e, fazendo uso de sua habilidade e força física, dominar o animal e tombá-lo para poder em seguida manietá-lo completamente e matá-lo. Para tal, faz-lhe uma incisão no pescoço procurando a jugular, da qual brota imediatamente um grande jorro de sangue, que é depositado em um balde - esse sangue é depois vendido para o consumo. Em cerca de cinco minutos, o animal fica dessangrado e, após verificar que este já não reage, o açougueiro começa a retirar-Ihe o couro para logo desmembrá-lo e eventrá-lo. Algumas mulheres, acompanhadas de crianças, se encarregam de cortar e lavar as vísceras do animal.

Durante esse processo, o matador fica impregnado de sangue. Sua relação com o animal é direta e a violência exercida é necessária para se obter o fim desejado. Uma série de percepções primárias causa forte impressão ao observador externo: o sangue, os pedaços de carne que são cortados e expostos, produzindo uma certa sensação de obscenidade (um ultraje ao nosso pudor, que é apenas resistência cultural ao que presenciamos), já que formaram parte de um ser que estava vivo há apenas alguns instantes. Essa obscenidade nos remete à matança como espetáculo. $\mathrm{Na}$ ação de matar um boi, encontramo-nos diante de um espetáculo cuja repetição faz pensar em uma rotinização do horror. É essa habituação ao horror uma das intuições-chave do texto, escrito em meados do 
século XIX, de Esteban Echeverría (1993 [1851]), que nos apresenta um matadouro povoado por seres degradados pela insensibilidade, transformados em massa amorfa sem individual idade que acabam matando um dissidente político da mesma forma que se mata o gado.

O trabalho de M aría Victoria Uribe, M atar, rematar y contramatar (1978), faz referência às mutilações infligidas aos cadáveres das vítimas da violência política que flagelou o Toliman* durante os anos 50 . Estes cortes tinham um conteúdo simbólico; imprimiam uma mensagem de terror, utilizado para exercer um controle social determinado em um momento de convulsão política. As mutilações apresentavam características similares aos cortes que se faz no gado em diversas tarefas rurais (castração, esquartejamento etc.). Segundo a autora, as pessoas que mutilavam os cadáveres de suas vítimas eram as mesmas que se relacionavam violentamente com o mundo animal. A relação violenta que impera entre o camponês e a natureza que ele deve dominar (situada além das conhecidas idealizações citadinas da vida bucólica) se desloca para a relação vítima-algoz - deslocamento, é certo, que não é direto nem automático, pois obviamente nem todos aqueles que desempenham tarefas nas quais se exerce violência sobre animais exercem violência sobre pessoas. Por outro lado, é necessário esclarecer que os Casares cometeram homicídios contra os Ramallo, mas não mutilavam suas vítimas. Em todo caso, proponho-me a afirmar que a forma como certas pessoas do mundo rural exercem violência contra outros homens está impregnada de costumes e usos que se desenvolvem no domínio violento sobre os animais.

\section{As brigas de galos}

Parece-me que eu o estivera vendo quando saiu com o galo debaixo do braço. Adverti-Ihe que não fosse procurar uma desgraça no galinheiro e ele me mostrou os dentes e me disse: cala-te que nesta tarde vamos nos encher de cobres (Gabriel García Márquez 1972).

Os Casares têm um passatempo e uma paixão: as brigas de galos. Participam delas combinando, às vezes, suas apostas com as de Walter, que também lida com reses no matadouro. Walter dedica a maior parte de seu tempo livre à criação e preparação de galos de briga. "Os galos

\footnotetext{
* Um dos departamentos administrativos da Colômbia, cuja capital é Ibagué [N.T.].
} 
para mim são tudo, são mais importantes que as mulheres". J unto com ele está sempre Ricardo, seu companheiro inseparável, "o tolimense", um amigo de uns 40 anos que ensinou a ele vários truques na arte de preparar galos. Ricardo trabalha em uma padaria. Os Casares e outros amigos acompanham esses dois em suas aventuras, emprestando a eles seus galos para pô-los na rinha ou apostando nos galos deles em suas brigas.

Existem dois rinhadeiros na comunidade. Um se encontra no bairro mais pobre, chamado "Simón Bolívar", um bairro operário também conhecido, mais informalmente, como "bairro chinês". Trata-se do melhor rinhadeiro. É um recinto circular com tribunas onde podem acomodar-se até oitenta espectadores. Possui um relógio para definir exatamente a duração das brigas, e o juiz que se faz presente tem um aspecto quaseprofissional. São também ali maiores as apostas, assim como a quantidade e qualidade dos galos que se apresentam. $O$ outro rinhadeiro se localiza em uma área igualmente marginal da povoação, entre um grupo de casas que seguem o curso de uns riachos que passam pela vila. Esse rinhadeiro possui, aproximadamente, metade da capacidade do primeiro e é menos concorrido. As brigas realizam-se geralmente aos domingos, alternando-se entre os dois rinhadeiros, de modo que há atividade em cada um de quinze em quinze dias.

Antes de as brigas começarem, os diferentes galos são pesados e, de acordo com o peso do animal, escalam-se as rinhas. Em torno de cada galo se forma um grupo de torcedores que juntam, entre si, dinheiro suficiente para apostar contra a outra parte (no rinhadeiro do riacho, apostavam-se cem mil pesos entre os dois galos e no de Simón Bolívar, até duzentos mil). Para se chegar a essas somas é freqüentemente necessário apelar às relações de amizade. Com efeito, embora essas associações sejam muito flexíveis e ninguém tenha, em princípio, obrigação de apostar em um galo, na prática impõem-se certas solidariedades. Em primeiro lugar, são poucas as pessoas que criam galos e que também os preparam para a briga ou os lançam na arena. É muito comum que uma pessoa crie um galo e, chegado o momento de fazê-lo brigar, recorra a especialistas, ou solicite a outros com mais experiência, para prepará-lo, colocando nele as esporas (delicada tarefa, da qual pode depender a sorte do animal), ou para lançá-lo na arena. Por isso, em várias oportunidades, Walter apresentou galos seus com boa fama, mas logo viu seus lucros diminuírem ou desaparecerem por ter-se sentido obrigado a apostar em galos de amigos, mesmo os de fama duvidosa. Este é um dos momentos em que se percebe maior agregação social em uma comunidade em que a solidariedade tem poucas oportunidades de se expressar. No entanto, essa solida- 
riedade é, como tento explicar, essencialmente flexível e, lamentavelmente, só se exprime em oposição a outros, na contraposição entre diferentes grupos de apostadores. Essa forma de aposta, em que as relações pessoais e a lealdade entre grupos têm mais importância que o lucro, possui óbvias semelhanças com a aposta central descrita no artigo clássico de Clifford Geertz a propósito das brigas de galos em Bali (Geertz 1997: 349). Geertz refere-se ali a dois tipos de apostas: a aposta central, entre os atores principais, que é coletiva e envolve coalisões de apostadores reunidos em torno do dono do galo (nas quais se faz necessário apostar em um determinado galo quando a rede de relações sociais em que a pessoa está inserida assim o exige, independentemente da expectativa de vitória), e as apostas periféricas, que se realizam separadamente entre espectadores que procuram basicamente o lucro (Geertz 1997:349).

Os Casares, Walter e Ricardo associavam-se constantemente nas apostas. Ricardo arrumava os galos dos Casares e era quem os lançava na arena. Isto ocorria sempre que os Casares levavam um galo para brigar. Se não apresentavam galos, geralmente um deles estava presente e apostava com Ricardo. N as últimas rinhas que presenciei, porém, essa relação se havia desfeito, e cada grupo apostava independentemente.

Tendo-se em conta que não se recebe nenhuma gratificação especial para apresentar os galos na arena, e que ao custo de criar e preparar os galos deve somar-se o pagamento dos serviços do juiz, se as brigas ganhas e as perdidas forem equivalentes, a soma final seria zero. Embora os galistas sempre acreditem que seus galos são melhores que os dos outros, e embora existam aqueles que ganham muito mais que perdem, compreende-se imediatamente que a atividade a que se dedicam com tanta paixão não consiste no mais rentável dos negócios.

Durante a briga, os apostadores gritam e se movem freneticamente, no ritmo de seus galos, e as apostas continuam entre os que não participaram dos grupos iniciais. Está-se, então, diante de um modo de apostar semelhante ao das apostas periféricas descritas por Geertz (1997: 349). A catarse produzida por essa descarga de energia se faz visível especialmente quando se leva em conta a escassez de atividades recreativas na comunidade. A crescente-se a tudo isso o fato de as rinhas de galos serem, em mais de uma ocasião, cenário de brigas que, em al guns casos, levaram os envolvidos a agredir-se fisicamente com faca ou pistola. Há uns dois anos, um rinhadeiro que se encontrava na entrada da vila foi fechado depois de uma pessoa ter sido morta à bala na seqüência de uma discussão. 


\section{Os Casares e a vingança de sangue}

A partir do momento em que a violência intestina rechaçada pelo sacrifício revela ligeiramente sua natureza, apresenta-se, como acabamos de ver, sob a forma de vingança de sangue ou 'blood feud', que não desempenha em nosso mundo mais que um papel insignificante ou até nulo. Talvez seja aí onde convenha procurar a diferença das sociedades primitivas, a fatalidade específica de que nos livramos e que o sacrifício não pode, evidentemente, descartar, mas apenas manter dentro de certos limites toleráveis (Girard 1983:14).

$\mathrm{N}$ a vila, os Casares são classificados como pessoas com as quais é melhor não provocar enfrentamentos. Em uma altercação, eles podem apelar a um último recurso: "não se metam comigo que estou disposto a tudo". O desafeto corre o risco de contrair um inimigo para toda a vida, uma pessoa que pode levar o enfrentamento às últimas conseqüências (ou seja, ao emprego da violência física contra ele ou contra a sua família) e que não esquecerá a afronta.

Não é estranho, portanto, que uma das afirmações ouvida várias vezes, em diferentes conversas, com distintas pessoas, seja que "essa é uma vila calma, aqui não acontece nada, desde que não se tenha um inimigo". O que é um inimigo? “Um inimigo é alguém que está sempre lhe procurando, que não Ihe permite ficar tranqüilo porque você sabe que em algum momento lhe pode fazer mal".

Como se constrói um inimigo? “Quando se está bebendo, ou durante um trabalho, pode-se dizer coisas a al guém que o desagradem, e há pessoas muito rancoristas (sic) que não esquecem e não perdoam". Outras vezes, "briga-se por dinheiro ou por terra ou por mulheres". Um inimigo rompe as regras do jogo social, assumindo todas as conseqüências negativas que possam recair sobre sua pessoa, mas, ao mesmo tempo, obrigando o outro a viver na incerteza e no perigo. Ele decide, por ele e por seus inimigos, viver uma vida baseada na insegurança. Por exemplo, em um pleito por terras, o inimigo abandonará a discussão jurídica e tratará de decidir o litígio amedrontando ou agredindo fisicamente o adversário ou sua família.

O relato a seguir, que narra a série de atos de vingança ocorridos no ano de 1995 entre as famílias Casares e Ramallo, não constitui o único caso de violência em que a família focalizada se viu envolvida. Há uns quatro anos, um irmão do chefe da família Casares foi morto à bala em uma loja, sem que ninguém pudesse informar-me sobre os motivos do acontecido. 
A família Casares, há pouco menos de um ano, alugava uma casa dos Ramallo. Naquela época, a relação entre eles era considerada boa, e seus membros eram freqüentemente vistos bebendo juntos - uma das formas sob as quais se expressa a amizade na comunidade analisada. Parece que os Casares atrasaram por alguns meses o pagamento do aluguel. A mãe Ramallo exigiu deles o pagamento durante uma forte discussão, que terminou em ameaças e insultos. Nesse momento, essa muIher entregou a um de seus filhos uma faca de açougueiro e o incitou a matar o pai Casares. (As mulheres, neste e em outros casos anal isados, apenas excepcionalmente agem diretamente nas ações violentas, ainda que estejam presentes incitando os homens à ação e avivando as chamas do conflito.) Em lugar do pai Casares, porém, seu filho mais novo, que estava presente na discussão, interpôs-se, tendo morrido esfaqueado.

Como naquela época o Exército estava presente na área, soldados prenderam o assassino e sua mãe, ainda que esta tenha sido liberada pouco tempo depois. Um dos Ramallo, que se encontrava preso no momento do feito e que era, ademais, muito temido na vila, foi solto, voltou para sua casa e deparou-se com aquela situação. Acusou os Casares pelo sucedido e, quinzes dias depois, de noite, homens mascarados entraram na casa dos Casares e assassinaram à bala o pai.

Cerca de seis meses depois, o pai Ramallo teve de comparecer à vila para pagar alguns impostos. Estava acompanhado de sua filha de mais de 30 anos, de uma neta de 6 e de sua mulher. Enquanto esta esperava na tesouraria, seu marido, sua filha e sua neta foram buscar boletos de impostos que ficaram na casa anteriormente alugada pelos Casares. Para resgatá-los, deveriam necessariamente passar em frente ao açougue de seus inimigos. Ao fazê-lo, foram provocados pelos Casares para uma discussão feroz, durante a qual foram trocados todo tipo de insultos (interessante notar que, além dos vitupérios que se referiam à desonestidade das respectivas mães, as pessoas que presenciaram o início da discussão recordam especialmente o uso do epíteto "perros"). Quando voltaram a passar, um dos Casares os esperava com uma pistola, matando os dois adultos com vários disparos. Ao verificar que ambos estavam mortos, guardou a pistola debaixo do seu cinturão e se afastou caminhando. Nessa oportunidade, uma mulher foi vitimada pela agressão; fato incomum, mas, neste caso, tratava-se da aplicação estrita da lei de talião. Vários entrevistados acham que se os Ramallo não tivessem assassinado o filho mais novo dos Casares, isso não teria acontecido. Em todo caso, não ocorreu ao agressor matar a neta de 6 anos. 


\section{Os ritos fúnebres}

A cerimônia final, todavia, envolve a reafirmação da sociedade manifesta pelo fim do luto e pela crença de que a alma foi incorporada pela sociedade dos mortos e assentou-se da mesma maneira que a consciência coletiva dos vivos foi assentada pelos rituais funerários (Bloch e Parry 1989:4).

No enterro de dom Narciso Casares podem-se ver elementos próprios à morte de um "pater familiae" assassinado em conseqüência de uma série de atos de vingança. Na igreja paroquial foi realizada uma missa pelo morto assistida por cerca de 250 pessoas; muitas outras esperavam do lado de fora. Essa foi a cerimônia católica propriamente dita, já que o padre participou apenas dela e a liturgia restringiu-se à ortodoxia. O padre abençoou os restos mortais na saída do templo e, com isso, deu por encerrada sua participação no ritual. Depois da missa e da benção, uma multidão de aproximadamente oitocentas pessoas acompanhou o cortejo do féretro até o cemitério. Por que a expressão de solidariedade foi tão maciça? Desenvolvi em outro artigo a descrição dos grandes enterros de homens mortos violentamente, associados ao culto heróico pela comunidade (Alvarez 2001:4043). Ademais, devemos ter em conta que, neste caso, Nómeque considerou os Ramallo culpados, devendo seus parentes mais distantes justificar defensivamente suas opiniões. Por outro lado, houve uma profunda expressão de solidariedade entre os matadores e açougueiros da área, que custearam parte dos gastos do enterro e, especialmente, pagaram os músicos.

Durante o trajeto até o cemitério, uma banda de mariachis interpretou diversas canções, entre elas "Ninguém é eterno no mundo" e "A cruz de madeira", que fazem referência à morte, à conseqüente separação e à necessidade de manter vivos a lembrança e o culto do ente querido desaparecido.

O costume de levar mariachis aos funerais não é considerado tradicional; sua introdução é de data recente. Para a maioria, essa prática (que, nessa comunidade, se dá apenas em enterros de homens) é de clara origem narco (narcotraficante) e é reservada, de acordo com meus informantes, a homens que se destacaram na comunidade ou que morreram tragicamente. Os mariachis foram vetados recentemente pela I greja Católica nas cerimônias fúnebres da região. Segundo rumores, a proibição se deveria à expressa disposição do bispo, que consideraria o costume como "próprio de pagãos".

Quando chegaram ao túmulo, e enquanto o coveiro e alguns parentes que o auxiliavam cuidavam de terminar de cavar a sepultura, os ma- 
riachis voltaram a entoar as mesmas canções. Depois, o trompetista tocou a alvorada e fez-se um minuto de silêncio, interrompido por uma avalancha de soluços majoritariamente femininos que acompanharam, ruidosamente, a colocação do féretro na cova.

Posteriormente, na saída do cemitério, os familiares entregaram aos presentes cervejas e refrigerantes que foram consumidos por todos os participantes. Esta última ação poderia ser considerada, de acordo com a clássica opinião de Durkheim (1993) e Robertson Smith (1889), como um ato de comensalidade. Naquele exato momento, os parentes do sexo masculino próximos do morto se reuniram e cochicharam em voz baixa. Um deles disse: "Isso não pode ficar assim, é a segunda morte em um mês".

O momento de maior solidariedade social coincide também com aquele utilizado para planejar uma possível vingança. Dois dos momentos em que a unidade familiar se expressa como tal, em que se manifesta a existência mesma da família, são a vingança de sangue e os rituais fúnebres. Para Durkheim (1993), essas duas coisas estão diretamente relacionadas. A dor coletiva levada em alguns casos ao paroxismo nos ritos fúnebres produziria a necessidade de exteriorizar esse sentimento por meio da vingança. A mbos formariam parte de um mesmo mecanismo social, em que uma desgraça comum reaviva os sentimentos coletivos e reforça nos dois casos os laços sociais. Uma observação detida da família Casares parece corroborar esta afirmação. A série de vendetas uniu a família que praticamente só se move como coletivo ante o temor de uma revanche. Por outro lado, olha-se para fora do círculo familiar com receio e desconfiança. N unca se vê um Casares que não esteja acompanhado por outro. Geralmente, andam em três, dois na frente e um atrás, todos armados. Essa situação, conseqüência óbvia da possível vingança que paira sobre suas cabeças, os conduz necessariamente à união familiar e à sua separação do resto da comunidade.

\section{Discussões e conclusões}

A análise da situação de conflito intestino nos obriga a acentuar os aspectos culturais da violência subjacentes às suas condições estruturais. Um exame da violência que impera em comunidades como essa estudada que se baseie unicamente na perspectiva do conflito de classes seria insuficiente para produzir uma explicação razoável do fenômeno. De um ponto de vista estrutural, poderíamos definir a já referida atitude dos Casares de "estarem dispostos a tudo" e não terem medo de levar o confli- 
to até suas últimas conseqüências, como um mecanismo defensivo de classe. Este seria acionado pelos que, seguindo as regras sociais e legais, acabariam perdedores em qualquer entredito em que se vissem confrontados com pessoas de maior influência, melhores relações ou simplesmente maior educação formal, as quais terminariam por impor seu ponto de vista. Diante dessa inferioridade de condições, "estarem dispostos a tudo" Ihes permitiria romper o jogo social e ameaçar seus desafetos, arriscando tudo, inclusive suas vidas e as de suas famílias. Sua atitude seria assim análoga ao que J ames Scott chama de "as armas dos fracos". Para Scott (1985), as armas dos fracos constituem formas veladas de luta de classes, às quais um setor social em inferioridade de condições diante dos demais (especialmente em sua relação com o poder econômico e com o poder político) apela como forma de resistência. Mas, curiosamente, na comunidade analisada esse mecanismo acaba se impondo em casos de enfrentamento de pessoas de condições socioeconômicas iguais ou muito parecidas, como no caso acima descrito das famílias Casares e Ramallo. Ou seja, se a atitude referida constituísse um mecanismo defensivo de classe, por que as principais vítimas se encontram na mesma camada social? No meu entender, uma análise detida da agregação e desagregação social da comunidade analisada que, ao mesmo tempo, dê espaço à autonomia dos elementos culturais, faz-se necessária para explicar como um mecanismo social defensivo pode converter-se em um fator de conflito interno.

A análise da cultura local faz-me pensar na existência de um sentido de pertencimento familiar que produz uma auto-identificação em " face do mundo". Percebe-se no interior da família Casares um forte sentimento de pertencimento e solidariedade que contrasta com uma rede de relações externas fraca manejada com uma profunda desconfiança. N esse sentido, a já mencionada relação que Durkheim estabelece em As formas elementares da vida religiosa entre morte-ritos fúnebres e vendeta, como um ciclo que acentua a solidariedade do grupo social e marca suas diferenças com o exterior, parece adequada para descrever a agregação da família Casares. No entanto, demonstrações de solidariedade coletiva de toda a comunidade, como na maciça participação nos funerais do chefe da família, apontam para a complexidade do tema. É evidente que, para que exista uma comunidade, é necessária a existência de laços de solidariedade que assegurem a relação entre seus membros. Ora, é também evidente que nos deparamos aqui com uma comunidade dividida e confrontada internamente com uma situação que René Girard definiria como de "crise sacrificial" ou de violência generalizada. 
Para René Girard (1982; 1983), o sacrifício, fundamento de todo o sistema religioso, consistiria a princípio em uma violência real para depois se converter em violência simbólica. Primeiro, o sacrifício consistia em entregar um ser humano em holocausto; a seguir, este foi substituído por um animal, ao qual foram atribuídas características de humanidade (exemplo: o cordeiro); e, finalmente, transformou-se em um sacrifício meramente simbólico (exemplo: a missa). O sacrifício consistia em um ato que canalizava os impulsos violentos da comunidade para uma vítima determinada (o bode expiatório). A religião, pois, por via do sacrifício, estaria exorcizando a violência comunitária. A vingança de sangue, que para Girard seria um ato próprio dos povos chamados primitivos (incluiria ele, nesta categoria, o sul da Itália?), é evitada ao concentrar-se a violência em uma vítima determinada. Quando uma comunidade não consegue canalizar esses impulsos violentos, estaríamos diante de uma "crise sacrificial". Seria este o caso da comunidade de Nómeque?

Vejamos, em primeiro lugar, que a separação que Girard realiza entre primitivos e modernos Ihe permite obviar o problema da existência de sociedades camponesas sob o impacto da modernização (Calábria, Sicília, o altiplano cundiboyacense), nas quais a violência interna é característica e, ainda mais grave, obviar a discussão sobre a função da religião nessas sociedades. Com efeito, nas sociedades mencionadas, a "crise sacrificial" convive com a celebração constante do sacrifício da missa. Girard diz que o sacrifício não elimina completamente a violência, mas a reduz a limites "toleráveis", um adjetivo que ao invés de iluminar a solução do problema ajuda a obscurecê-lo ainda mais. Necessitaríamos talvez esboçar um índice de tolerabilidade? Por causa disso, embora nos encontremos diante de uma comunidade "enferma" do ponto de vista de sua coesão social, acreditamos que a "crise sacrificial" não seja uma explicação plausível para compreendermos os fenômenos em pauta. Seria necessário analisar com mais atenção a profunda complexidade dos fenômenos religiosos que não se esgotam no sacrifício e, em particular, as formas populares de religiosidade presentes no catolicismo tal como se desenvolvem na Colômbia, onde é possível "rezar para matar", quer dizer, orar solicitando à divindade as forças necessárias para a destruição do inimigo (como me foi pontualmente indicado). O material analisado sugere que a solidariedade da comunidade está seriamente ameaçada pela existência de agregações sociais internas que se identificam em contraste e em oposição umas às outras. A religião católica (agora em competição com uma miríade de grupos protestantes) foi incapaz de produzir uma vida religiosa que canalizasse socialmente os impulsos violentos presentes na comunidade. 
Existe ou não uma "cultura da morte" como elemento autônomo que incide diretamente no comportamento da comunidade, conforme defende Carlos Alberto U ribe (1988) para a Colômbia? A realização de trabaIhos que implicam um constante exercício de violência sobre os animais, a exposição a imagens sumamente violentas no contato com estes, às quais se teria de agregar as imagens de morte e agressão entre humanos a que desde pequenas as pessoas se vêem expostas, influem em seu comportamento embrutecido ou animalizado? Essas atitudes se refletem nas intuições de Echeverría e no trabalho de María Victoria Uribe anteriormente citados. A mbos tratam não tanto da "animalização" do algoz, mas da animalização da vítima, de um processo de "naturalização" mediante o qual esta última se vê desumanizada e integrada à natureza. Sem que eu tenha encontrado elementos de animalização tão contundentes como os cortes realizados nas vítimas durante o período da "violência", permanece o fato de que os membros masculinos da família analisada trabaIham em um ambiente de contato agressivo com o mundo animal, o açougue e, especialmente, o matadouro da vila, e que sua principal diversão são as brigas de galos. Como vimos, os Casares consideravam que os Ramallo deviam morrer "como perros".

Embora esses elementos, por si só, sejam insuficientes para estabelecer algum tipo de relação causal direta entre a violência exercida sobre animais e o assassinato de seres humanos, atrever-me-ia a afirmar que $o$ ambiente cultural das pessoas estudadas, tanto em suas atividades laborais quanto recreativas, está impregnado de uma cultura violenta e tanática (outros elementos a se levar em conta seriam a presença dos mariachis, somada ao tipo de canções interpretadas, que não são ouvidas somente no cemitério, mas fazem parte do repertório local, cuja análise pormenorizada implicaria um novo artigo). Outro aspecto não menos importante dessa cultura é o fato de a morte violenta acabar sendo considerada um elemento da cotidianidade. Ao fim e ao cabo, matar ou morrer assassinado é algo que sempre aconteceu e possivelmente acontecerá nessa vila.

Considero, pois, a partir desta análise, que o estudo dos elementos culturais é útil e necessário para que se possa compreender um mecanismo social - a vingança de sangue - que se desenrola entre pessoas de mesma classe social e que pode levar ao aniquilamento das famílias em confronto. A família, na cultura local, constitui uma agregação social que pode colocar-se em contraste viol ento com a solidariedade comunitária. A religião é incapaz de canalizar a violência existente na comunidade, ainda que, como foi dito, não pareça correto definir a situação como de 
"crise sacrificial". A violência está presente na cultura da família e da comunidade analisada tanto na forma da relação agressiva com a natureza como na cotidianidade do homicídio; como disse um camponês: "Senão, para que as pessoas carregariam uma arma?"

Recebido em 2 de dezembro de 2002

Aprovado em 3 de fevereiro de 2004

Tradução: J orge M attar Villela

Santiago Alvarez é professor de antropologia da Universidade $\mathrm{N}$ acional de San Martín. E-mail: <alvaresantiago@hotmail.com>

\section{Notas}

1 Existem dificuldades objetivas para se chegar a uma definição intercultural satisfatória do conceito de violência, como aponta David Richers em The anthropology of violence (Richers 1986:28). Preferi, para os fins deste trabalho, definir a violência em um sentido amplo como "toda ação humana que envolve a inflicção deliberada de sofrimento sobre outros" (Marvin 1986:121).

2 Os conflitos descritos neste artigo, entretanto, tiveram todos lugar no decorrer da pesquisa, tendo sido, portanto, diretamente observados.

3 A maioria das famílias na comunidade analisada era matrifocal, com o pai ausente ou com pouca presença no interior da casa. É evidente, no entanto, que nas famílias envolvidas em vendetas a figura paterna se torna mais relevante. Em minha tese, descrevi o modo como um ideal patriarcal que denomino patronagem [patronazgo] fracassa entre os camponeses pobres dada uma realidade que tende a expulsar os homens da casa. Esta impossibilidade masculina de pôr em prática esse ideal provoca freqüentes tensões no interior da estrutura familiar (ver Alvarez 1999:85-88). 


\section{Referências bibliográficas}

ADAS, M ichael. 1979. Prophets of rebellion: millenarian protest movements against the European colonial order. Chaper Hill: University of $\mathrm{N}$ orth Carolina Press.

ALVAREZ, Santiago. 1999. The relationship between internally and externally generated violence in an andean mestizo Colombian community. Ph. D. Thesis, London School of Economics.

. 2001. “Enterrando heróis, patriarcas, suicidas e traidores: solidariedade e ostracismo nos A ndes colombianos". Mana, 7(2):35-55.

BLACK-MICHAUD, J acob. 1975. Feuding societies. Oxford: Basil Blackwell.

BLOCH, Maurice e PARRY, J onathan (eds.). 1989. Death and the regeneration of life. Cambridge: Cambridge University Press.

DURKHEIM, Émile. 1993. Las formas elementales de la vida religiosa. Madrid: Alianza Editorial.

ECHEVERRÍA, Esteban. 1993 [1851]. El Matadero. Panamericana Editorial.

GARCíA MÁRQUEZ, Gabriel. 1972. El Coronel no tiene quien le escriba. Buenos Aires: Editorial Losada.

GEERTZ, Clifford. 1997. “J uego profundo: notas sobre la riña de gallos en Bali". In: La interpretación de las culturas. Barcelona: Gedisa.

GIRARD, René. 1982. “El misterio de nuestro mundo"; "Claves para una interpretación antropológica". In: Diálogos con J. M. Oughourlian y G. Lefort. Salamanca: Ediciones Sigueme.

.1983. La violencia y lo sagrado. Barcelona: Editorial Anagrama.

HOBBES, Thomas. 1975 [1651]. Leviathan. London: Everyman's Library.
HOBSBAWM, Eric. 1983 [1969]. Rebeldes primitivos. Barcelona: Ariel.

ISAACMAN, Allen. 1980. "Chiefs, rural differentiation and peasant protest: the Mozambican forced cotton regime, 1938-1961". African Economic History, 1(4):15-56.

LONDOÑO, Rocío. 1993. Los nuevos hacendados del Sumapaz. Bogotá.

MARULANDA, Elsy. 1991. Colonización y conflicto, las lecciones del Sumapaz. Bogotá: Tercer M undo Editores.

MARVIN, Garry. 1986. "Honour, integrity and the problem of violence in the Spanish bullfight". In: D. Richers (ed.), The anthropology of violence. New York: Basil Blackwell.

RICHERS, David (ed.). 1986. The anthropology of violence. New York: Basil Blackwell.

ROBERTSON SMITH, W. 1889. Lectures on the religion of the Semites. Edimburgo: A and C Black.

SCOTT, J ames. 1985. Weapons of the weak: everyday forms of peasant resistance. New Haven/London: Yale University Press.

STERN, Steve (org.). 1990. Resistencia, rebelión y conciencia campesina en Ios Andes. Lima: Instituto de Estudios Peruanos.

URIBE, Carlos A Iberto. 1988. “N uestra cultura de la muerte". Texto y Contexto, 13:53-67, Bogotá.

URIBE, María Victoria. 1978. Matar, rematar y contramatar. Bogotá: CINEP. 


\section{Resumo}

Este artigo descreve a vingança de sangue entre pessoas do mesmo estrato social em uma comunidade camponesa dos Andes colombianos. Embora esta comunidade esteja situada em uma zona de conflito político entre Estado e guerrilha, a relevância de suas dissensões internas é tal que o observador não pode eximir-se de registrá-las. Graves conflitos entre famílias desencadeiam séries de atos de vingança que freqüentemente conduzem ao aniquilamento dos membros masculinos desses grupos. Focalizando um desses conflitos, discute-se a existência de uma cultura da violência, com o objetivo de indicar a necessidade de levar em conta a conflituosidade interna subjacente aos fenômenos de resistência ou rebelião rural que dominam as investigações e os discursos a propósito da violência camponesa.

Palavras-chave Violência; Vingança; Colômbia; Camponeses

\section{Abstract}

This article describes blood revenge between people of the same social strata in a peasant community in the Colombian Andes. Even though this community is located within an area of guerrilla warfare against the state, the relevance of its internal quarrels can not be overlooked by the observer. Serious hostility between families provokes acts of revenge that frequently lead to the annihilation of the male members of these groups. Focussing on one such conflict, the existence of a culture of violence is discussed, in order to illustrate the need to take into account the internal antagonism that coexists with the phenomena of rural resistance or rebellion that dominate research and discussion on violence among the peasants. Key w ords Violence; Revenge; Colombia; Peasants 